\title{
Pinguicula antarctica Vahl and/or Pinguicula nahuelbutensis Gluch in the Cordillera de Nahuelbuta, Chile
}

S. Jost CASPER • Waldpark Seniorenpflegeheim • Prellerstraße $16 \cdot$ D-01309 Dresden • Germany - jost.casper@arcor.de

Keywords: Lentibulariaceae, Pinguicula antarctica Vahl, P. nahuelbutensis Gluch, distribution, Chile, Cordillera de Nahuelbuta.

Abstract: Two Pinguicula species occur in the Cordillera de Nahuelbuta, región Biobio, Chile: the Magellanic moorland herb $P$. antarctica Vahl (= P. chilensis Gay) and the Central Cordilleran highAndean herb P. nahuelbutensis Gluch (= P. chilensis auct. non Gay; = P. australandina Gluch).

\section{Introduction}

The Cordillera de Nahuelbuta and its flora have been always of particular interest to those studying Chilean botany. This range of comparatively low mountains, part of the Cordillera de la Costa, extends between the rivers Bio Bio $\left(\sim 37^{\circ} \mathrm{S}\right)$ and Imperial $\left(\sim 38^{\circ} 50^{\prime} \mathrm{S}\right)$ for about $175 \mathrm{~km}$ and culminates in the Altos de Nahuelbuta (1,533 $\mathrm{m}$ a.s.1.). It is characterized by the Nahuelbuta forest type, which is dominated by evergreen trees such as Eucryphia cordifolia, Aextoxicon punctatum, Laureliopsis philippiana, and Araucaria araucana at elevations above $\sim 1,000 \mathrm{~m}$ a.s.l. (Schulmeyer Malig 1978: 11, 23-24; Quintanilla Pérez 1983:118-121; Luebert \& Pliscoff 2004: 90-91; Smith-Ramírez 2004: 382). ${ }^{1}$ Its western slopes and its plateau are exposed to the offshore winds coming from the Pacific and get more than 3,000 $\mathrm{mm}$ of precipitation per year with frequent winter snowfall (Endlicher et al. 1988: 110, Abb. 5). It harbors many small creeks ("turberas"), lakes and ponds (lagunas; Fig. 2) that offer advantageous habitats for hygrophilous moorland herbs (Figs. 1, 2).

\section{Material and methods}

The study is founded on pieces of information by various botanists, especially of O. Gluch (Harthausen) and Prof. Dr. F. Hellwig (Jena), as well as on intensive literature and herbarium (SGO, CONC) studies.

Taxonomic treatment

The view of the Chilean auctorum veterum on Pinguicula in the Cordillera de Nahuelbuta

There are no reports of Pinguicula in the 19th century literature on the flora of the Cordillera de Nahuelbuta (Chile).

In 1877, F. and R. A. Philippi travelled across the cordillera for the first time. On November 16, 1889 R. A. Philippi (1896: 11) again visited the Cordillera de Nahuelvuta ${ }^{2}$ near Angol but did not cross the granite plateau. Apparently, he did not study the sector Las Turberas (Fig. 1) with its characteristic wetland vegetation. I found no corresponding Pinguicula-specimens at SGO.

\footnotetext{
${ }^{1}$ Also called 'Bosque resinoso templado de Nahuelbuta de Araucaria araucana' (Luebert \& Pliscoff 2006: 167-169) or 'Bosque resinoso templado costero de Araucaria auracana'). In recent decades, there has been a large-scale degradation of the natural vegetation as a result of the expansion of commercial plantations (Smith-Ramírez 2004: 382).

${ }^{2}$ Philippi and others may spell Nahuelbuta this way, as the local Mapuche don't know the letter $b$.
} 


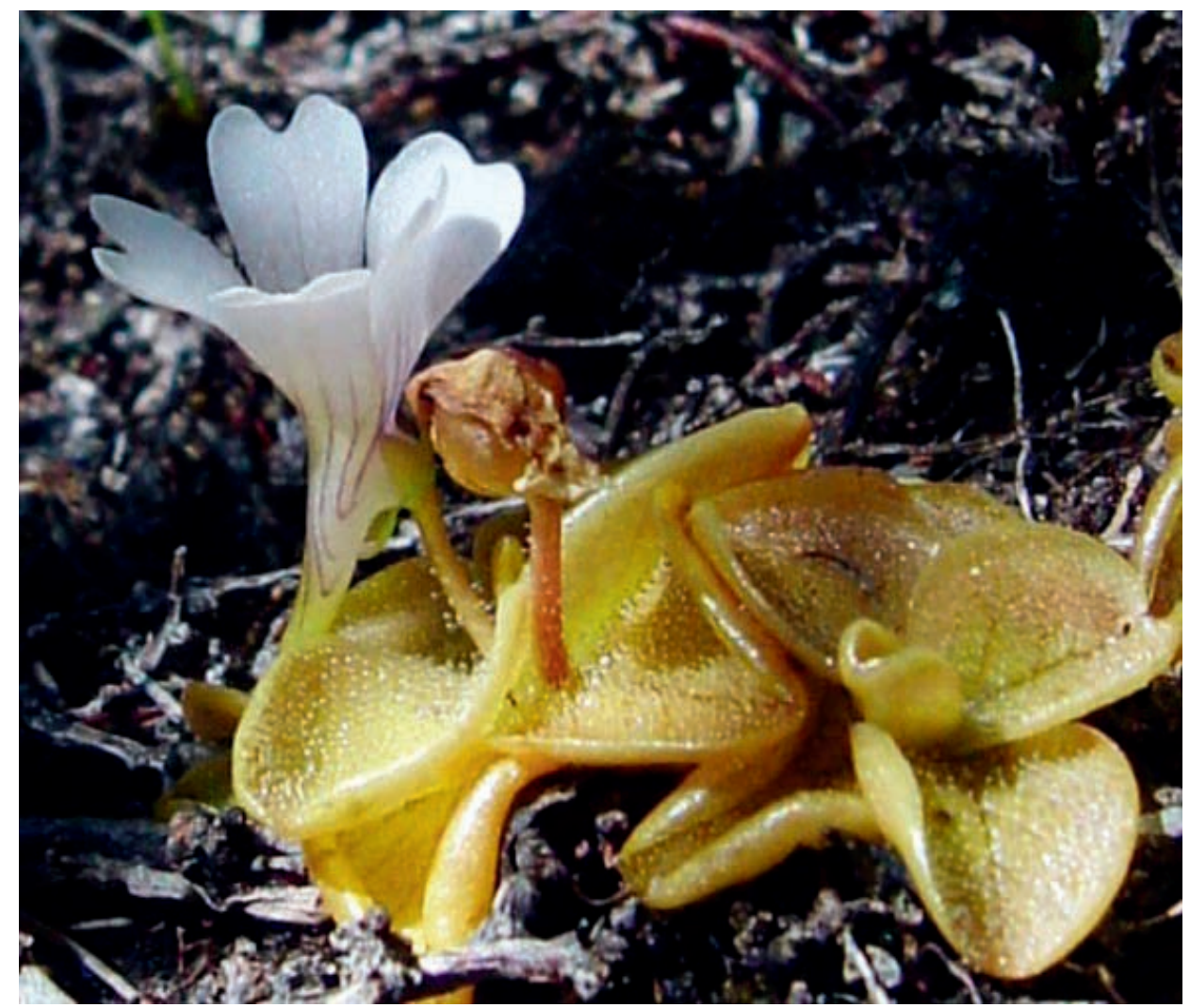

Figure 1: Pinguicula nahuelbutensis Gluch (initially quoted as 'form' of $P$. chilensis Clos), Nacional Parque Nahuelbuta, Las Turberas. Photograph: O. Gluch. Photocopy (slightly changed by J. Casper), with permission. [In Lampard et al. 2016: 412: Fig. 2.68 reproduced side-inverted].
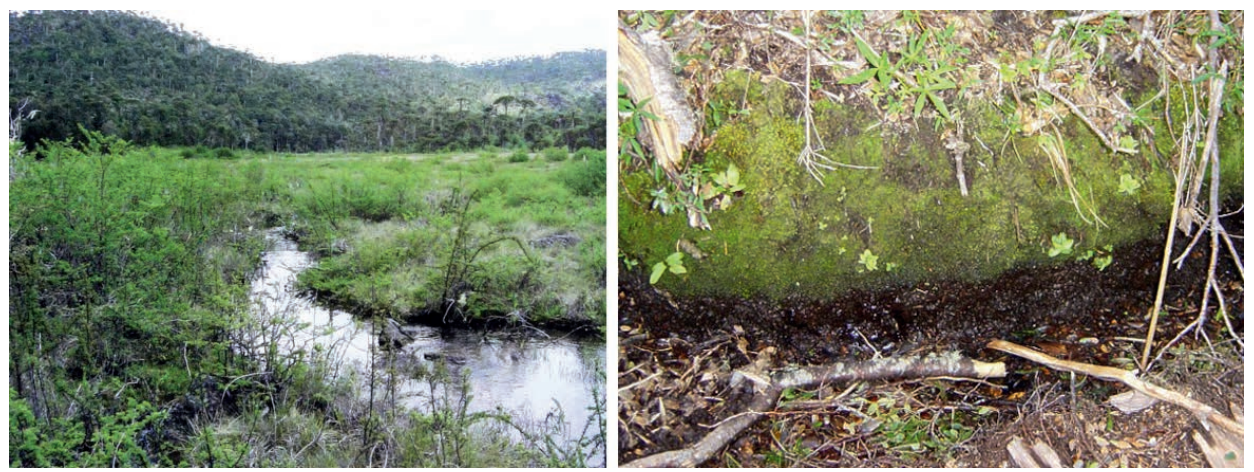

Figure 2: (Left) Parque Nacional de Nahuelbuta, plateau of Las Turberas. Main habitat of Pinguicula nahuelbutensis, in shadow places under grasses and shrubs: 'There is no Sphagnum' (Gluch 2007: 6). Photograph: O. Gluch, with permission. (Right) Parque Nacional de Nahuelbuta, Sendero El Aguilucho ( 1,200 m a.s.I.), moss cushion along a spring, sterile rosettes of Pinguicula nahuelbutensis. Photograph: O. Gluch, 03-10-2004. Photocopy: slightly changed by J. Casper, with permission. 
In 1897 C. Reiche ${ }^{3}$ visited the 'Küstencordillere von Nahuelbuta' and studied intensively flora and vegetation of the sparse Araucaria araucana-forest ("lichten Araucarienwald") at an elevation of between $\sim 1,000 \mathrm{~m}$ and $\sim 1,500 \mathrm{~m}$ a.s.l. He vividly described the vegetation, especially the sites of "Fagus antarctica" (represented by Nothofagus antarctica, Nothofagus dombeyi, and Nothofagus pumilio) and Araucaria araucana with its typical understory vegetation (Reiche 1897: 7-9; 1907: 225-226 ${ }^{4}$ however, he did not mention Pinguicula nor any other taxon of the Magellanic moorland herbs. Was he unaware of habitats like cushion peat bogs or turberas?

Naturally, Philippi and Reiche were aware of the biogeographical importance of the Araucaria forest in the Cordillera de Nahuelbuta however, they apparently did not fully realize the special situation of the mountain range. This is not mysterious-Smith-Ramírez (2004: 385) has shown that acceptable collections of native plants in the area (such as those currently stored in SGO or CONC) were rarely made before the major deforestation of 1920-1940.

In January 1909 Reiche visited the area again (Moreira Muñoz \& Muñoz Schick 2013: p. XXX, tab. 2). From this botanical excursion 72 specimens are housed in SGO, beyond it one dried 09 R[1909 Reiche; Fig. 3$]^{5}$. The specimens show distinctly elongated scapes measuring up to $\sim 80 \mathrm{~mm}$ (!). This length of the fruiting scapes corresponds well with that of typical P. antarctica.

In his vivid report of the excursion in 1897 he did not mention any Pinguicula although he entered the mountains from the village Cañete and reached the Araucaria zone on the hill-top (apparently his "pinales") perhaps having passed the Sendero de Aguilocho $(1,275 \mathrm{~m}$ a.s.1.). Here, in the gra-

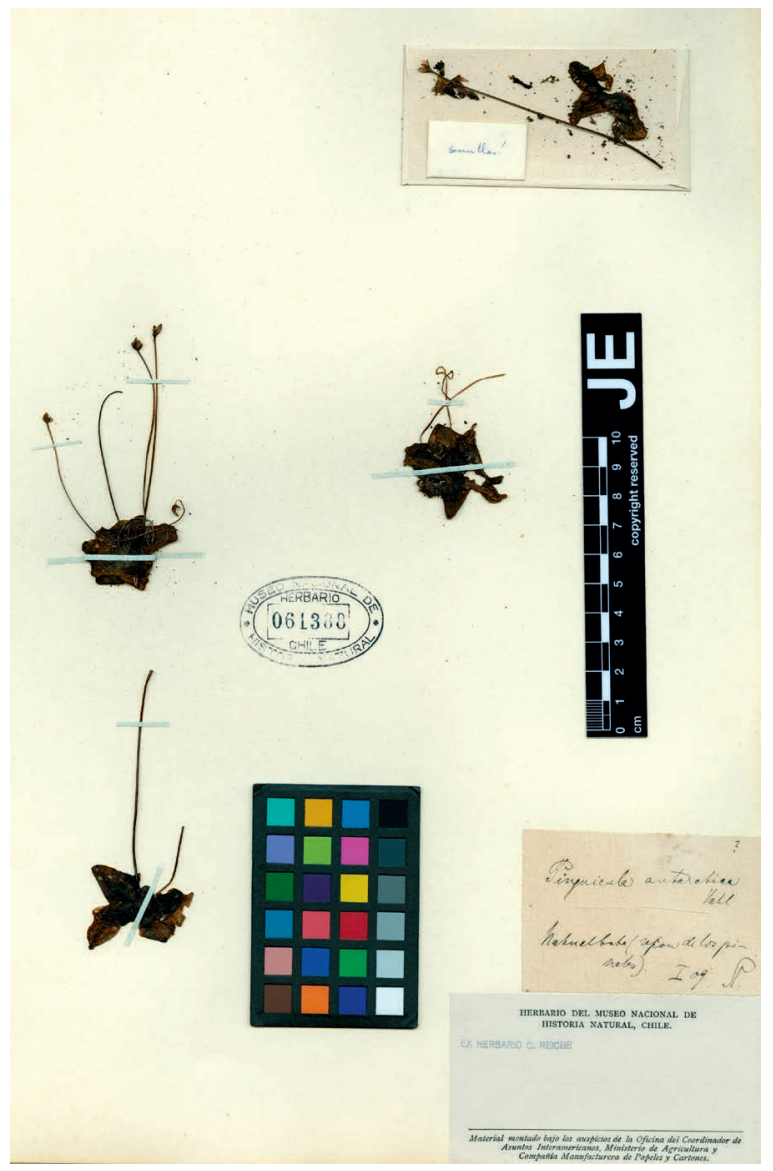

Figure 3: Pinguicula antarctica Vahl, collected by C. Reiche (see the handwritten signature 'R' on Pinguicula identified as '? P. antarctica Vahl' [SGO 061388: 'Nahuelbuta (región de los pinales) I. the label righthand, bottom) in the Cordillera de Nahuelbuta (region de los pinales) in January 1909. Photocopy of SGO 061388; with permission.

\footnotetext{
${ }^{3}$ Moreira Muñoz \& Muñoz Schick (2013: XXVII, XXX, Tab. No. 2) report for 1897 only 'Maule', however for 1909 'Nahuelbuta', the latter confirmed by the specimen deposited in SGO (Fig. 3).

${ }^{4}$ Reiche's report is repeated basically in ([Reiche, C.] 2013: 321-323).

${ }^{5}$ Ex Herbario C. Reiche; the label handwritten by C. Reiche: the letter 'R' (right-hand corner bottom of the label) stands for Karl Reiche as Taylor \& Muñoz-Schick (1994:147, Fig. 3) have pointed out.
} 
nitic Coimallín area, with numerous sites such as Cerro La Piedra El Águila (1,379 m a.s.1.) ${ }^{6}$, Cerro Anay (1,400 m a.s.1.), Trongol Alto etc. (see our annotated list of specimens) he apparently did not detect the squat Pinguicula, named P. nahuelbutensis by Gluch.

In 1909, he must have encountered the cushion peat bogs, with their little lakes, in the Las Turberas sector-while he did not mention them on his Pinguicula antarctica collection (SGO 061388) no other locality is known for this species in the Cordillera de Nahuelbuta! In his "Estudios criti$\cos . . . "(1910)$ we find repeatedly annotations like "Drosera uniflora ...Cordillera de Nahuelbuta, ca. 1,300 m” (p. 439), "Rubus geoides... Cordillera de Nahuelbuto (Enero 1909)” (p. 440), "Donatia fascicularis... en pantanos de la Cordillera de Nahuelbuta, ca. 1,300 m" (p. 441)7, "Perczia [sic] bellidifolia...Cordillera de Nahuelbuta..." (p. 442). They indicate his collection activities in the area in January 1909, but not the exact area.

The Reiche-collection is important for taxonomy and plant geography: Taxonomically it shows that two Pinguicula species occur (or occurred?!) in the Cordillera de Nahuelbuta: P. antarctica and P. nahuelbutensis, the first species known from Antarctic moorlands or peat bogs, the second reported from mallines (alpine stony wet meadows in the Central Chilean Andes). In the Cordillera de Nahuelbuta, however they apparently grow together. Plant geographically the now confirmed occurrence of $P$. antarctica in the Cordillera de Nahuelbuta closes the putative gap in the area of P. antarctica in the Chilean Coastal Cordillera: the taxon in question is said to occur in the Cordillera Pelada in the south as well as in the "Cordillera de Culico" (región de Maule) in the north skipping the Cordillera de Nahuelbuta.

Summarizing the view of the auctorum veterum of the Chilean flora about the taxonomic nature of the Pinguicula of the Cordillera de Nahuelbuta we have to state that not Philippi nor Reiche quote the genus expressis verbis. Merely a single specimen collected by Reiche has been handed over to us named correctly P. antarctica. A direct comparison of Reiche's quotes with other Pinguiculaspecimens in SGO or CONC is impossible at time.

The modern botanist's perspective on Pinguicula in the Cordillera de Nahuelbuta

Schulmeyer-Malig (1978) studied in detail climate, geomorphology, and vegetation of the Cordillera de Nahuelbuta and compared her results with the classification scheme proposed by Oberdorfer (1960) and Schmithüsen (1956). She completed the regional plant geography of the mountain area near the coast and drew especial attention to the occurrence of Araucaria araucana, the characteristic species of Oberdorfer's Carici Araucarietum, at an elevation of between 1,260 m and $1,400 \mathrm{~m}$. Because of her predominant interest in the vegetation of the "bosques naturales" she did not discern the existence of the understory dwarf Pinguicula living in these regions.

Quintanilla Pérez (1983: 118), describing the vegetation of the Cordillera de Nahuelbuta, pointed out that "hacia los 700 metros se desarrolla el bosque de (op. cit. 119) araucaria asociado con Nothofagus ...en la cordillera de Nahuelbuta ...Existen, por ejemplo, en el área ...especies cuya distribución es propria de Magallanes [!], constituendo este sector, precisamente, su limite septentrional como es el caso de plantas carnivoras autotrofas unicas de Sudamérica... Son 2 plantas carnivoras chilenas: la Drosera ...Luega esta la Pinguicula antarctica ...en el pais se extienden desde la cordillera de Nahuelbuta hasta Tierra de Fuego.

Translated, this reads:

Araucaria forests (with Nothofagus) occur at altitudes of up to $700 \mathrm{~m}$, in the cordillera de Nahuelbuta... In this area, there exist species that are otherwise distributed only in the

\footnotetext{
${ }^{6}$ Cerro La Piedra Águila is a 'peñon rososa en la cima de la Cordillera'.

${ }^{7}$ Looser (1952: 8) quoted Reiche's specimen of Donatia fascicularis as follows: 'Nahuelbuta. 1300 m., 1/1909, Reiche.'
} 
Magellanes region[!]. making this sector the northern border exemplified with the only autotrophic carnivorous plants of South America. There are two groups of carnivorous plants in Chile: Drosera species and Pinguicula (Pinguicula antarctica) ....in this country from the Cordillera de Nahuelbuta till Tierra de Fuego.

We didn't find any Pinguicula specimen collected by Quintanilla Pérez however, his quoting of a species "de Magallanes" seems to indicate that he indeed thought of Vahl's P. antarctica when describing the vegetation of the cordillera. His quoting remained the single concrete indication in the Chilean botanical literature before 2000 .

Schulmeyer-Malig as well as Quintanilla Pérez overlooked Montero Ortiz' collection of "Pinguicola (sic) antarctica" in the southernmost portion of the Cordillera de Nahuelbuta, in the reach of La Cabaña-Villa Las Araucarias (province Cautin, Carahué; $38^{\circ} 43^{\prime} \mathrm{S}, 73^{\circ} 10^{\prime} \mathrm{W}$ ), about $90 \mathrm{~km}$ south of the Nacional Parque, in 1972 (Plantae Chilensis No. 8880, CONC 97724; Fig. 4).

In 1997 Casper spent several hours (so to speak en passant) at the Botanical Garden MünchenNymphenburg, during which he examined Pinguicula herbarium sheets for identification. Among them was M-0243983 from Nahuelbuta which he identified as P. chilensis Clos (Fig. 3). He was aware that his identification contrasted to the common opinion of the existence of $P$. antarctica in the range. ${ }^{8}$ However, he did not infer further taxonomic consequences.

Between 2004 and 2006 O. Gluch visited repeatedly the Parque Nacional de Nahuelbuta. He found Pinguicula chilensis Clos in two different habitatssmall populations in the forest at springs along the El Aguilucho trail (Fig. 2 Right) at an altitude about 1,200 $\mathrm{m}$, and larger populations in the Las Turberas area. This is a plateau at an altitude of 1,250 $\mathrm{m}$ where "small creeks form a kind of a bog" (Gluch 2000: 6; see also the impressive photograph p. 7, fig. 1; cf. Fig. 2 Left). Here Gluch detected the main populations of Pinguicula especially in
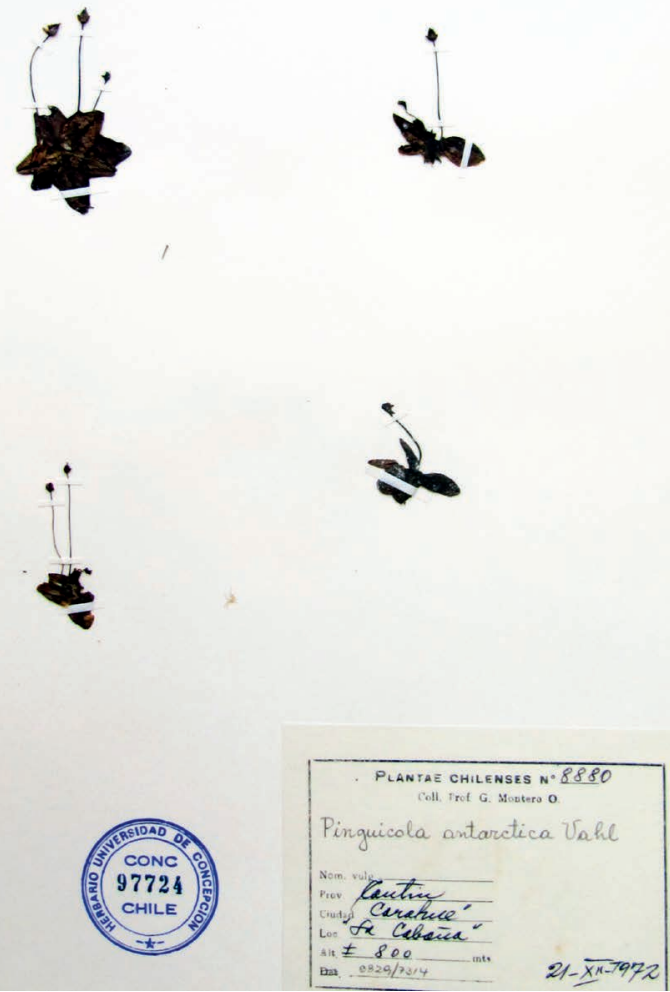

Figure 4: Pinguicula nahuelbutensis, Cautin, Carahué, 'La Cabaña', \pm 800 m: specimen collected by G. Montero Ortiz, 21. XII. 1972, Plantas Chilenses No. 8880 [CONC 97724, det. Pinguicola (sic) antarctica Vahl]. Photocopy. With permission.

${ }^{8}$ Rodriguez et al. (2000) laconically reported the occurrence of $P$. chilensis Clos in the Cordillera de Nahuelbuta. Their anatomically oriented study didn't discuss taxonomical or plant geographical aspects (Cf. CONC 156147; Fig. 3). 

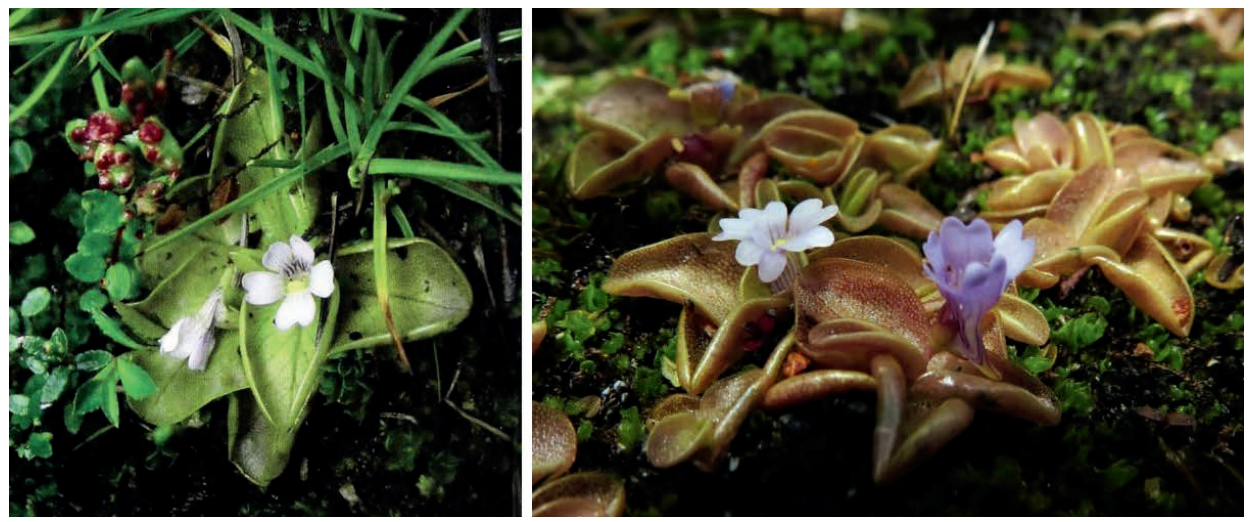

Figure 5: (Left) Pinguicula nahuelbutensis, Cordillera de Nahuelbuta, plateau of Las Turberas; flowers in front and profile view. Photograph: O. Gluch (photocopy (slightly changed J. Casper), with permission. (Right) Pinguicula nahuelbutensis, Cordillera de Nahuelbuta; short-scaped, white and blue flowering specimens. Photograph: C. Chappuzeau-Roldan. Photocopy, with permission.

shaded areas under grasses. He also noted the presence of Drosera uniflora, and the absence of Sphagnum.

Initially Gluch (2004; cf. Lampard 2016: 414) thought that the Pinguicula he had observed and photographed was $P$. chilensis Clos. He noticed the short scape (at most $\sim 15 \mathrm{~mm}$ tall) giving the small herb a squat shape (Fig. 2). He later became aware that this feature did not fit perfectly with the species description by Gay, and concluded his specimens might represent a slightly variant "form" of $P$. chilensis. Subsequently, the detection of the extreme short flower-and fruit-scapes in the populations led him to the plants as a new species, namely P. nahuelbutensis (Gluch 2017: 10). This new species is said to be endemic to the Parque Nacional de Nahuelbuta. ${ }^{9}$ In contrast, Gluch had observed heavily elongated (up to $110 \mathrm{~mm}$ tall) scapes $^{10}$ in $P$. antarctica from the Cordillera Pelada.

Gluch measured short scapes (up to $\sim 12 \mathrm{~mm}$ ) in specimens at the Sendero El Aguilucho $(1,264$ $\mathrm{m}$ a.s.1.; $\sim 37^{\circ} 49^{\prime} \mathrm{S}, \sim 73^{\circ} 01^{\prime} \mathrm{W}$; Fig. 1). From his photographs and the specimen M-0243983 ${ }^{11}$ we can see that $P$. nahuelbutensis seems to be distinguished by its squat build, which is due to its extremely short scape. The five blue to whitish lobes of the nearly equal-sized five corolla lobes (Fig. 5) are longer than wide, and are distinctly notched up to $2 \mathrm{~mm}$ at the distal margin.

In profile the white tube is slender, distinctly funnel-shaped, i.e. at the throat (distally) widest, (proximally) mostly gradually tapering and running without any constriction into the comparatively long and thin length axis of the tube. The bases of the corolla lobes, the tube, and the spur are longitudinally violet parallel-veined.

\footnotetext{
${ }^{9}$ Holotype: Chile, Prov. Malleco, Parque Nacional de Nahuelbuta, 1250 m, 7. 1. 1968. Ricardi, Marticorena, Matthei 1831. - M-0243983! (Det. - rev. Pinguicula nahuelbutensis spec. nov. Oliver Gluch, München 29. 8. 2017; det. J. Casper 1997 P. chilensis Clos; Fig. 7 (Lecto-) Isotype (designated here): Chile. Prov. Malleco. Dept. Angol. Parque Nacional de Nahuelbuta.

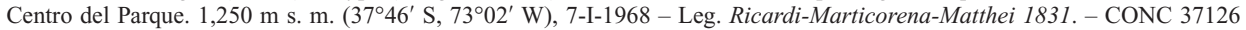
(! Det. Pinguicula antarctica Vahl. The original handwritten label runs: 'RMM 1831 Pinguicula chilensis Clos CM 1984)'.

${ }^{10} \mathrm{He}$ emphasized that in the Chilean coastal mountainous range the known Pinguicula habitats typically correspond to the antarctic (magellanic) peat bog vegetation with Sphagnum magellanicum and Donatia fascicularis. Such habitats occur from the Tierra Fuego along the coast up to the Cordillera Pelada and farther to the North and normally harbor P. antarctica.

${ }^{11}$ Gluch had not gathered any specimens for drying. So, he was compelled to choose a specimen deposited in an herbarium. His choice was M-0243983, representing specimens which don't clearly show the structure of the flowers. See Fig. 5 (CONC 156147) for clarification.
} 
Gluch ascertained that the remarkable length of the fruiting scape observed is a meaningful feature of $P$. antarctica however, not of the putative P. chilensis Gay. Therefore, he did not hesitate to identify Gay's taxon with Vahl's $P$. antarctica: He replaced it by his new P. australandina.

I agree with Gluch's observation of the obvious different length development of the generative scapes in Pinguicula. However, I do not agree with his assessment that the feature is suited to discriminate taxa within the species $P$. chilensis auct. non Gay. In our opinion, in this context the scape length (among other characteristics!) is well suited to discriminate taxa on species level: $P$. antarctica Vahl and P. nahuelbutensis Gluch are well differentiated, good species.

\section{The La Cabaña-Villa Las Araucariales-Pinguicula and Araucaria araucana}

Although most of the botanists studying Pinguicula in the Cordillera de Nahuelbuta reported its occurrence together with Araucaria araucana they were not aware of its exact area. Not until Hauenstein-Barr's (2012: 29) information “...en turbales o pantanosos turbosos preferencia a altitudes superiores a los 800 metros... P. chilensis [= P. nahuelbutensis $]$ desde ... La Cabaña-Villa Las Araucarias" (cf. Carahué, $\sim 38^{\circ} 31^{\prime} \mathrm{S}$; CONC 97724) the southern sub-population became public. Now it was evident, that the area of our butterwort in the Chilean Coastal Cordillera is nearly congruent with that of the outstanding Chilean conifer (Fig. 6).

In the southernmost portion of the Cordillera de Nahuelbuta a second site of Pinguicula exists. The four well preserved mostly faded specimens on CONC 97724 (Fig. 4) show all the features of the cline of $P$. chilensis auct. non Gay. That means: The La Cabaña-population shows the typical P. chilensis auct. non Gay-shape. It is P. nahuelbutensis and not, as originally believed, $P$. antarctica. In contrast, the NP Nahuelbuta-population shows the squat $P$. nahuelbutensisbuild. Nevertheless, $P$. chilensis auct. non Gay and $P$. nahuelbutensis Gluch are members of a single cline: they belong to the same species as will be demonstrated in detail in a forthcoming study (Casper, Hellwig \& Manitz in prep.).

\section{Distribution and habitat of \\ P. nahuelbutensis in the \\ Cordillera de Nahuelbuta}

In the Cordillera de Nahuelbuta (Chile, Cordillera de la Costa) Pinguicula nahuelbutensis occurs especially in the area between the center of the Parque Nacional Nahuelbuta and the Laguna de la Totoras at an altitude of about 1,240 m a.s.l., as well as on the trail E of Cañete

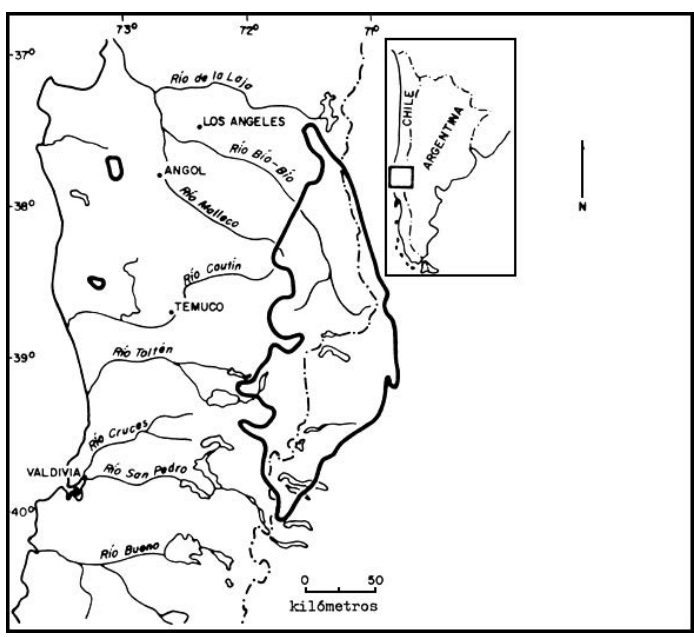

Figure 6: Araucaria araucana, distribution; area black circled. The two small circled areas left-hand are nearly identical with the sites of Pinguicula nahuelbutensis in the Cordillera de la Costa: the upper greater one situated in the PN de Nahuelbuta (CONC 37126), the lower smaller one situated near Villa Las Araucarias (CONC 97724). After Hechenleitner et al. 2005: 44; cf. Marticorena \& Rodríguez 2005: Page 319, fig. 145. Photocopy. 
at the entrance to the Parque Nacional at an altitude of 1,460 $\mathrm{m}$ a.s.1. moreover, in the húmedal near Cerro Anay $(1,400 \mathrm{~m}$ a.s.1.), and at Alto Nahuelbuta (1,450 m a.s.1.). It was found in a turbera (cushion peat bog) of Trongol Alto south of Curanilahué, too.

It is also known from La CabañaVilla Las Araucarias ( $90 \mathrm{~km}$ south of Cañete) in the range of the Altos de Tirúa (Cautin-Carahué).

Its area coincides to a high degree with the distribution range of Araucaria araucana (Fig. 6): Cordillera de Los Andes $\left(37^{\circ} 03^{\prime}-40^{\circ} 03^{\prime} \mathrm{S}\right)$ and Cordillera de Nahuelbuta $\left(37^{\circ} 40^{\prime}-38^{\circ} 29^{\prime} \mathrm{S}\right)$.

In the center of the Nahuelbuta mountain range $P$. nahuelbutensis grows in wet places as the border of small springs (Sendero de Aguilucho; Fig. 1) and creeks or at the side of little ponds or lagunas in the so-called sector Las Turberas (Fig. 7).

It has to be proved whether the Pinguicula reported from pollen analytical studies in the Laguna Las Totoras (Villagrán 2001: 797, Fig. 3) belongs to $P$. antarctica (so in the said study p. 799 , zona Altos de Pabilo II, Cordillera de

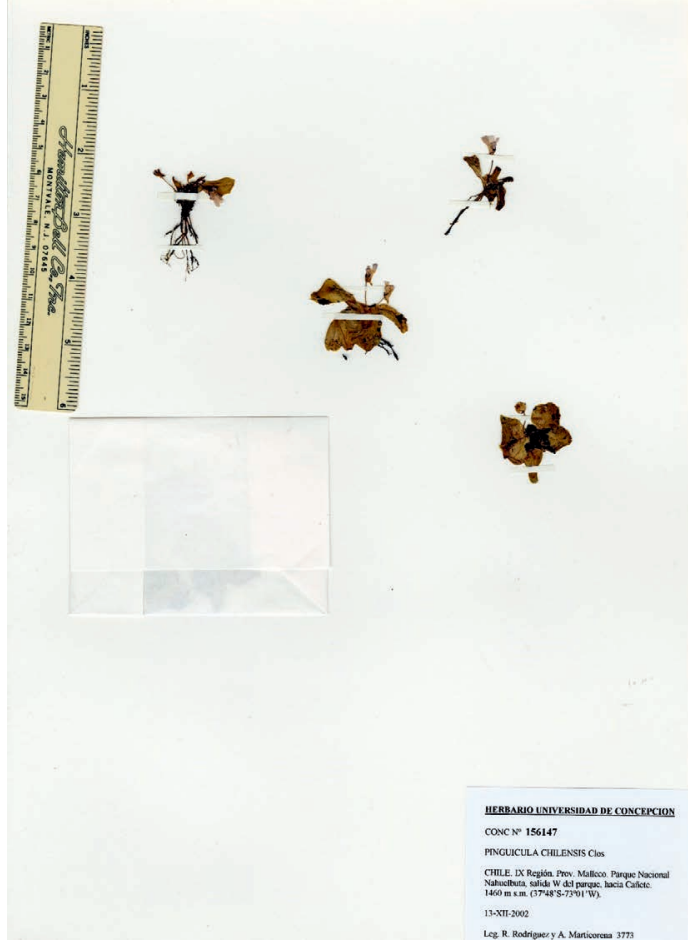

Figure 7: Pinguicula nahuelbutensis, Chile, Prov. Malleco, Parque Nacional Nahuelbuta, salida W de parque, hacia Cañete. $1460 \mathrm{~m}$ s. m. CONC No. 156147 (R. Rodríguez \& A. Marticorena 3773, det. Pinguicula chilensis Clos). Photocopy; with permission. Sarao) or to P. nahuelbutensis.

In its Cordillera Central main area, the taxon occurs in sub-Andean meadows often called mallins, flown through by melt water from glaciers, or in high-Andean mires.

As a whole, the habitat of $P$. nahuelbutensis is quite different from the typical Magellanic moorland (cushion peat bog) habitat of P. antarctica and of its characteristic companions Astelia pumila, Donatia fascicularis, and Sphagnum magellanicum.

\section{Conclusions}

The present study is the preceding part of a critical and comprehensive taxonomic investigation on the genus Pinguicula in South America (Casper, Hellwig \& Manitz in prep.). This preliminary study gives pieces of information about the nature and distribution of the taxon in the Chilean Cordillera de Nahuelbuta in the hope of additional and critical expert advice.

In the range the two species $P$. antarctica Vahl and P. nahuelbutenis Gluch (= P. chilensis auct. non Gay; P. australandina Gluch) occur, the first in the so-called Magellanic moorlands, the second in mallin- (pantano-) like habitats of the Araucaria araucana region in the Nacional Parque de Nahuelbuta $\left(\sim 37^{\circ} 49^{\prime} \mathrm{S}, \sim 73^{\circ} 01^{\prime} \mathrm{W}\right)$ and in its immediate northern neighborhood (Trongol Alto: 
$\left.\sim 37^{\circ} 39^{\prime} \mathrm{S}, \sim 73^{\circ} 04^{\prime} \mathrm{W}\right)$. Moreover, a sub-population of $P$. nahuelbutensis is found in the Altos de Tirúa (sector La Cabaña-Villa Las Araucarias) in the south of the Cordillera $\left(\sim 38^{\circ} 43^{\prime} \mathrm{S}, \sim 73^{\circ} 10^{\prime} \mathrm{W}\right)$.

In the present context I don't discuss the nomenclatural and plant geographic implications in detail. This will be done in the forthcoming comprehensive study announced above.

\section{References}

Casper, J., Hellwig, F., and Manitz, H. (in prep.). Pinguicula chilensis Gay, Pinguicula australandina Gluch or Pinguicula nahuelbutensis Gluch? A botanical-taxonomical search for clues. Gayana (In preparation for print).

Endlicher, W., Mäckel, R., and Schulmeyer, D. 1988. Contulmo - eine deutsche Siedlung in der Cordillera de Nahuelbuta (Mittelchile). Ibero-Amerikanisches Archiv N. F. 14(1): 103-124.

Gluch, O. 2020. Oliver Gluchs Welt der Fleischfressenden Pflanzen. Pinguicula australandina Gluch (2017). Pp. 1-2. http://www. Gluch.info/pingu67.htm. Accessed 4 March 2020.

Gluch, O. 2000. My experiences with the southernmost butterwort Pinguicula antarctica. Intern. Pinguicula Study Group Newsletter 10: 23-26 [with an addition by H. Lührs pp. 26-27].

Gluch, O. 2004. Pinguicula chilensis Clos (1849). Pp. 1-6. [Pinguicula chilensis in the "Parque Nacional Nahuelbuta", Chili by Oliver Gluch, October 3, 2004, pp. 4-6 (included)]. http://www. pinguicula.org/pages/plantes/pinguicula_chilensis.htm. Accessed 4 March 2020.

Gluch, O. 2007. Pinguicula chilensis - habitat observations from the Nahuelbuta National Park in Chile. Carnivorous Plant Newsletter 36(1): 6-8.

Gluch, O. 2010. Oliver Gluchs Welt der Fleischfressenden Pflanzen. Pinguicula australandina Gluch (2017). Pp. 1-9 (13 photos: 1 photo 2101 2005, 1 photo 2601 2007, 9 photos 0602 2010). http://www.gluch.info/ping67_1.htm\#chil2. Accessed 4 March 2020.

Gluch, O. 2017. Revision of Pinguicula (Lentibulariaceae) in Chile and Argentina. Carnivorous Plant Newsletter 46(4): 121-131.

[Gluch, O.:] Pinguicula australandina Gluch (2017), pp. 1-3. [Oliver Gluchs Welt der Fleischfressenden Pflanzen...] http://www.gluch.info/pingu67.htm. Accessed 4 March 2020.

Lampard, S., Gluch, O., Robinson, A., Fleischmann, A., Temple, P., McPherson, S., Roccia, A., Partrat, E., and Legendre, L. (Ed. Robinson, A.S.) 2016. Pinguicula of Latin America. 8 (not paged) +351-712. Redfern Nat. Hist. Prod. Poole, Dorset, England

Looser, G. 1952. Donatia fascicularis de la Cordillera de Nahuelbuta. Revista Universitaria (Universidad Católica de Chile) Ano 37(1): 7-9.

Luebert, F., and Pliscoff, P. 2004. Clasificación de pisos de vegetación y análisis de representatividad ecológica de áreas propuestas para la protección en la Ecorregión Valdiviana. Documento No. 10. Ser. Public. WWF Chile. Valdivia, Chile.

Moreira Muñoz, A., and Muñoz Schick, M. 2013. Carlos Reiche, Fundador de la geografía botánica de Chile. In [Reiche, C.] Sagredo Baeza, R. (Gen.-Ed.): Geografía Botánica de Chile. pp. IXXXXIII. Santiago de Chile. Pontificia Católica Universidad Chile.

Oberdorfer, E. 1960. Pflanzensoziologische Studien in Chile, ein Vergleich mit Europa. Flor. Veg. Mundi. 2: 1-208. Weinheim, Bergstraße.

Philippi, R.A. 1896. Botanische Exkursion in das Araukanerland. Abhandl. Ber. XLI Ver. Naturk. Kassel Vereinsjahr 1895-96: 1-31. Kassel.

Pliscoff, P. 2003. Priorización de áreas para fortalecer la conservación de la flora arbore nativa en la zona mediterránea de Chile. Tesis, Facultad Ciencias Universidad Chile, Santiago.

Quintanilla Pérez, V. 1983. Biogeografía. In (Anon.) Instituto Geográfico Militar: Geográfia de Chile III. 230 pp. Santiago. 
Reiche, K. 1897. Vorläufige Mitteilung über die Flora in den chilenischen Cordilleren von Curicó und Linares. Bot. Jb. 23: 628-629.

Reiche, K. 1907. Grundzüge der Pflanzenverbreitung in Chile. In Engler, A. \& Drude, O.: Die Vegetation der Erde VIII: XIV + $374+33$ Taf. +2 K. - Leipzig. [Pinguicula chilensis p. 218]

Reiche, C. 1910. Flora de Chile. Tomo Quinto. Familias 59(Conclusion)-83. Estudios críticos sobre la Flora de Chile. Pp. 1-463 (Pinguicula 86-88). Santiago de Chile.

Rodriguez, R., Urbina, A., and Valenzuela, S. 2000. Estudios anatomicos en Pinguicula chilensis Clos (Lentibulariaceae). Gayana Botánica 57(1): 101-103.

Schmithüsen, J. 1956. Die räumliche Ordnung der chilenischen Vegetation. Forschungen in Chile. Bonner Geograph. Abh. 17: 1-86.

Schulmeyer Malig, D. 1978. Observaciones fitogeográficas sobre la Cordillera Nahuelbuta. Boletin Informativo IGM. II trimestre: 11-27. Santiago, Chile, Instituto Geográfica Militar.

Smith-Ramírez, C. 2004. The Chilean coastal range: a vanishing center of biodiversity and endemism in South American temperate rainforests. Biodiversity Conservation 13: 373-393.

Taylor, M.C., and Muñoz-Schick, M. 1994. The botanical works of Philippi, father and son, in Chile. Ann. Missouri Bot. Gard. 81: 743-748.

Villagrán, C. 2001. Un modelo de la historia de la vegetación de la Cordillera de la Costa de Chile central-sur: la hipótesis glacial de Darwin. Revista Chilena Hist. Nat. 74(4): 793-803.

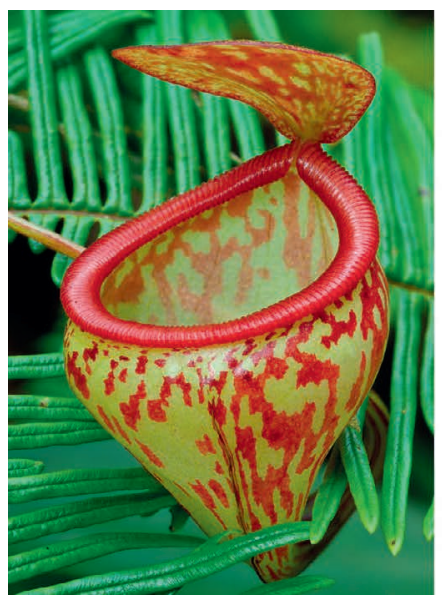

\title{
wistuba.com
}

Pitcher plants and other botanical treasures

\section{The World's Largest Selection of Nepenthes and Heliampora species}

\author{
Wistuba Exotic Plants I Dr. Andreas Wistuba \\ Friedhofweg 4, 88437 Maselheim, Germany \\ nepenthes@wistuba com
}

\section{Cascade Carnivores}

Mexican PIngulcula

- Butterworts are our specialty!

Utricularla

- Terrestrial and eplphytic

Nepenthes rure th

- Hiahland species/curtivars

Drosera, Dlonaea, Drosophyllum and more.

Website-www.cascadecarnivores.com

Email - support@cascadecarnivores.com Phone-425.336.1420 